\title{
Women's Language Features Used by a Woman Who Masquerades as a Man in Mulan (2020) Movie
}

\author{
Natasha Ayalus Yoan Yola Yolanda \\ Sanata Dharma University, Yogyakarta, Indonesia \\ natashaayyy@gmail.com \\ Barli Bram \\ Sanata Dharma University, Yogyakarta, Indonesia \\ Corresponding author \\ barli@usd.ac.id
}

\section{Article History}

Received: 20 January 2021

Reviewed: 26 January 2021

Accepted: 22 March 2021

Published: 27 April 2021

\section{Highlights}

the gender roles in society take part in forming someone's speech.

\begin{abstract}
Men and women use language differently related to their social status in society. Women, who are expected to be polite, tend to use some particular linguistic features that weaken their speech for the sake of politeness. To understand this phenomenon, this paper was conducted to explore the use of women's language features by a woman character who masquerades as a man in Mulan (2020) movie. It showed how a woman construct her speech differently from men to maintain her status in society through the analysis of the women's language features that are used by the character Mulan as a man and as a woman in Mulan (2020) movie. This study was qualitative research that used a document analysis method to analyze the data. Two observation checklist tables and a frequency comparison table were used to help the researchers to categorize the data for interpretation. The results that showed the percentage of the women's language features from Mulan's utterances when she played a role as a woman was $83.33 \%$ and then decreased to $58.82 \%$ when she played a role as a man. The results also showed that the gender roles in society take part in forming someone's speech. The decreasing point proved that playing a role as a man helped Mulan to feel more confident to state her ideas in society.
\end{abstract}

Keywords: gender, women's language feature, Mulan (2020) movie

\section{Introduction}

Language is the main tool of communication. It connects people through words that can show people's feelings and ideas. The ability to use language to communicate helps people to be able to maintain their social life relationships in society (Kurniaty, 2018). This relationship between language and society is a phenomenon in human's daily life that encourages people to discuss it through a study called sociolinguistics. Holmes (2013) conveyed that "Sociolinguistics examines the way people use language in different social contexts to provide a wealth of information about how language works, as well as about the social relationships in a community, and the way people convey and construct aspects of their social identity through their language". It helps people to cover the roles and impacts of language use for society and vice versa.

In sociolinguistics, the use of language in society is influenced by many factors, including gender. According to the Oxford dictionary, gender is "the fact of being male or female, especially when considered concerning social and cultural differences, not 
differences in biology." ("Gender", 2015, p. 632). In case that women and men share different roles and different social statuses in society, they share different ways of using language, too. According to Adriani and Soethama (2018), women are in a subordinate group where they must avoid offending others and have to speak politely. They have to be more careful in using language to maintain their social status in society. Therefore, they have their own ways to construct their speech appropriately to society (Lakoff, 1975). According to Lakoff (as cited in Holmes, 2013), there are ten women's language features that women use to differ their speech from men's. Those features are lexical hedges or fillers, tag questions, rising intonation on declaratives, 'empty' adjectives, precise color terms, intensifiers, hypercorrect grammar, 'superpolite' forms, avoidance of strong swear words, and emphatic stress.

In this research, the researchers were interested in analyzing the women's language features found in Mulan (2020) movie. The researchers chose the women's language features as the topic because it has an important role to show women's personal identity. It can give the explanations of how and why women and men speak differently in society. Therefore, it would be interesting to analyze the data from a character who plays two gender roles in society as seen in Mulan (2020) movie. This movie is a live-action movie that tells an adventure of a woman who masqueraded as a man to save his father from death while joining a war for the country. The researchers wanted to find whether or not the main character of this movie, Mulan, experienced her women's language features decrease or disappear when she hid her true identity to play a role as a man.

\section{Language and Gender}

According to Eckert and Mcconnell-Ginet (2003), language and gender are a study that discusses the relationship between gender and the use of language which covers the gender roles and the resources of the linguistic system to construct the social meaning. Gender roles in society cause women and men to share different language features in their speech to differentiate their roles and social status in society. Lakoff (1975) explained that the result of the natural gender of women impacts the language features that they use. Society depicts women as graceful and polite beings that know how to speak and behave. This identity influenced women's language feature that they use to communicate with their addresses to maintain and increase the solidarity between them and their addresses (Wahyuningsih, 2018).

\section{Women's Language Features}

In 1975, Lakoff introduced ten linguistic features of women's speech that differentiate them from men. Those features are lexical hedges or fillers, tag questions, rising intonation on declaratives, 'empty' adjectives, precise colour terms, intensifiers, hypercorrect grammar, 'superpolite' forms, avoidance of strong swear words, and emphatic stress.

\section{a. Lexical Hedges or Fillers}

Hedges and fillers are pause shaped form phrases that are used to fill the breath gap in a conversation (Wardani \& Kristiani, 2017). This feature is used to indicate women's insecurity and uncertainty about the ideas they want to express. This feature can be used for some purposes, such as stating a declaration (I guess), delivering a question ( $I$ wonder), and expressing uncertainty (I guess, well). 


\section{b. Tag Questions}

In linguistics, tag questions are grammatical forms that function to turn declaratives into questions in order to seek confirmation. This feature is commonly used in a declarative statement when the speaker already has a prediction of the response of their addressees (Apridaningrum \& Angelina, 2019). Lakoff (1975) argued that women used this feature to avoid conflict with their addressees. By using this feature, women let their addressees choose their sides, to confirm whether they agree with the ideas or not. The examples of this feature are isn't it?, is that right?, Do you agree?.

\section{c. Rising Intonation on Declaratives}

In linguistics, raising intonation uses to indicate a question. It usually used by people who expect to keep their conversation on by seeking feedback or response from others whenever they feel uncertain about things they said (Lubis \& Bahri, 2020). As a woman language feature, this feature indicates women's fears for making a decision. For example:

$$
\begin{aligned}
& \text { A: Where will we go? } \\
& \text { B: Around seven o'clock? }
\end{aligned}
$$

In the conversation above, speaker B answers speaker A's question with a declarative using rising intonation that indicates a question. It made speaker A should decide and confirm the main decision of that conversation.

\section{d. Empty Adjectives}

There are two types of adjectives that Lakoff stated in her book, neutral words (great, terrific, cool) and women's words (adorable, charming, sweet). These words, in fact, can be used by both women and men. It will not mark the user as feminine or effeminate. However, as it is assumed and called women's words in society, most men prevent themselves to use those words to maintain their status.

\section{e. Precise Color Terms}

Lakoff (1975) stated that "women make far more precise discrimination in naming colors than do men". This case is influenced by the gender role in society, where women are not expected to make decisions on important matters like men do. The use of precise color terms like beige, lavender, aquamarine, and so on are considered as one of the women's ways to take roles in making decisions for non-crucial things. They use this feature to show that they are good in this field (Susanti \& Aryani, 2018)

\section{f. Intensifiers}

Intensifiers is a linguistics term for a vocabulary that the function is to emphasize an utterance to affirm its meaning in a sentence (Yunnisa, Arman \& Amstrong, 2020). This feature can be used both by women and men, but it is more frequent in women's language (Lakoff, 1975). For example, women would say "I like him very much" or "I like him so much" to show clearly that their feelings are at a great level.

\section{g. Hyper-correct Grammar}

Lakoff (1975) found that the use of Hyper-correct grammar by women has been taught since they were young. It is because women are more prone to neologism than men. Therefore, women tend to use consistent standard forms to maintain their social status 
in society. They prevent themselves to drop the g's of the verbs like goin' or singin' or to modified words like "am not" to "ain't" or "don't know" to "dunno" because it will make their utterances sound rough for the addressees.

\section{h. 'Superpolite' Forms}

Women are positioned as polite beings that are not supposed to talk and act rough in society. This gender perception makes women avoid constructing their speech in form of a strong statement. For example, while asking others to do something, women prefer to use a simple request rather than a direct order. Furthermore, women are also experts at euphemism, know the right things to say to others, and more careful than men to say polite words like "please" and "thank you".

\section{i. Avoidance of Strong Swear Words}

Swear words are kinds of interjection that are used to express strong emotions (Janah \& Tarwiyah, 2017). Lakoff (1975) argued that men's position of strength in society allows them to use strong expressions to express themselves as individuals. Therefore, women avoid using strong swear words like shit or damn and prefer weaker forms, such as oh dear, fudge and goodness.

\section{j. Emphatic Stress}

When people are afraid of their words are not being listened to or not being taken seriously, they will throw extra ways into it to make the message received well by the addressees. For this reason, women put emphatic stress on their speech to strengthen its power and enhance the opportunity of getting other's attention. For example, women may say "It was a brilliant performance".

\section{Method}

This research analyzed the impacts of gender roles for someone's language use as seen in women's language features found in a woman's character that played two gender roles in Mulan (2020) movie. In conducting this research, the researchers used qualitative research. Hancock, Ockleford and Windridge (2009) stated that qualitative research aims to help people to understand the social world in which we live and why things are the way they are. The researchers found that qualitative research is the most suitable method for this research since this research is conducted to give a better understanding of how language is used differently by women considering their roles in society.

There are some types of qualitative research and the researchers chose content analysis to process the answers to the research questions in this research. Wambolt (as cited in Bengtsson, 2016) stated that "Content analysis is a research method that provides systematic and objective means to make valid inferences from verbal, visual, or written data to describe and quantify specific phenomena". The phenomena analyzed in this study were women's language features used by a woman who masqueraded as a man and the content was from the utterances of that woman, Mulan.

The data were collected from Mulan's utterances while she appeared as a woman and then pretended as a man. The researchers watched the movie several times and noted Mulan's utterances to be listed in the observation checklist tables. Each utterance 
was put into the appropriate tables, Mulan's table or Hua Jun's table. Then, the researchers categorized them into ten women's language features based on Lakoff's (1975) theory to be analyzed and interpreted as the answers to the research questions in this research.

\section{Findings and Discussion}

\section{A. Women's Language Features Found in Mulan (2020) Movie}

From the data, the researchers found that there were 82 Mulan's utterances in Mulan (2020) movie. 48 (52.54\%) were her utterances as a woman named Hua Mulan, and the other 34 (41.46\%) were her utterances as a man named Hua Jun. From these utterances, the researchers found 60 women's language features which consisted of 14 lexical hedges/fillers (23\%), 0 tag questions $(0 \%), 3$ rising intonation on declaratives $(5 \%), 3$ 'empty' adjectives (5\%), 0 precise color terms (0\%), 6 intensifiers (10\%), 8 'hypercorrect' grammar (13\%), 7 'superpolite' forms (12\%), 0 avoidance of using swear words (0\%), and 19 emphatic stress (32\%).

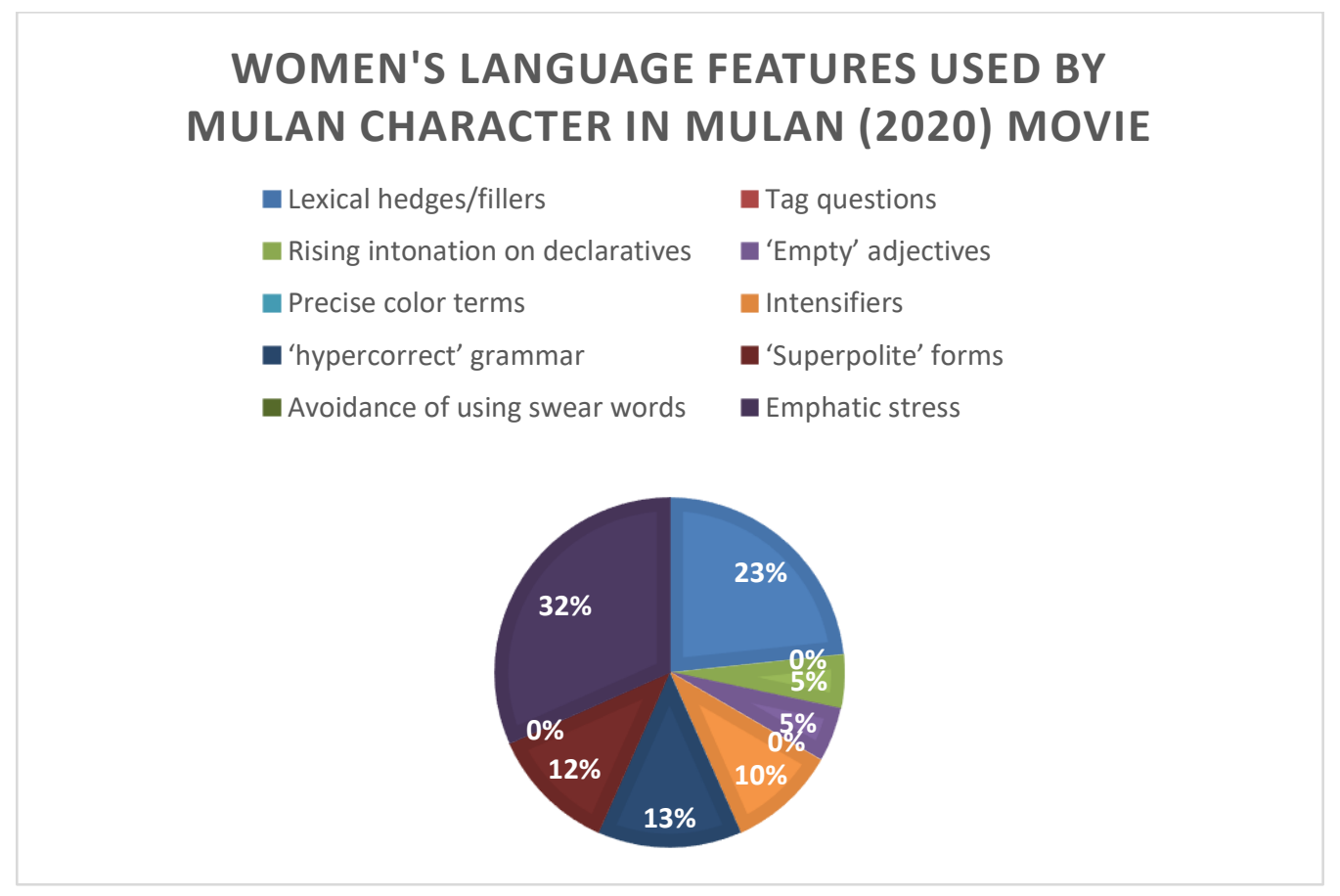

Figure 1. Women's Language Features Used by Mulan Character in Mulan (2020) Movie

\section{Lexical Hedges/Fillers}

According to Lakoff (1975), lexical hedges/fillers are a feature that indicates women's uncertainty in expressing their ideas for some particular situations. This feature is considered as one of the women's ways to protect themselves from making certain 
statements, show their deference to their addressees, and for the sake of politeness. As this feature came as a second place from the data analysis, it can be assumed that Mulan oftentimes faces difficulty to hold on in a conversation. This feature showed that Mulan was easily felt insecure to make a certain statement that may cause a conflict between her and her addressees.

\section{Example 1:}

Matchmaker: It's ideal for the teapot to remain in the center of the table.

Mulan : Yes, I understand. But I think the teapot should remain where it is.

Example 1 showed a conversation between Madam Matchmaker and Mulan that happened in an unpleasant situation. From that conversation, it can be seen that Mulan used the lexical hedges "but" and "I think" in her utterance to express her uncertainty while replying to madam matchmaker's statement. The lexical hedge "but" indicated her uncertainty in refusing the idea from madam matchmaker. Meanwhile, the lexical hedge "I think" indicated her uncertainty to state her idea. The situation was confusing for her because there was a spider under the teapot that can mess the situation up since her sister was afraid of that. On the other side, she also considered the rule that she should be polite and granted madam the matchmaker's words to prevent the title disgrace for her family.

\section{Example 2:}

Hong Hui : Are you matched? Can I ask?

Mulan (as Hua Jun) : No, I mean yes, I was. Hm, almost. Didn’t work out.

In example 2, Mulan felt insecure to answer the question from Hong Hui. She knew that the context that Hong Hui meant was whether she experienced matched with a woman or not. The answer was no for matched with a woman, but yes for experienced matched. Therefore, she used the lexical hedge I mean and filler Hm to express her uncertainty of the correct answer for that question.

The examples above showed that Mulan used lexical hedges/fillers in her utterances to hold on in a conversation that happens in an unpleasant situation. She used lexical hedges/fillers to get a little longer time to state her statement since she was unprepared for the conflict that may come after. The other reason she used this feature was to weaker her statement to express her politeness in form of not forcing others to agree with her. This feature indicated Mulan's uncertainty about what she said and her disbelief of winning a conversation through her own words.

\section{Rising Intonation on Declaratives}

According to Lakoff (1975), women used the rising intonation on declaratives feature on their utterances to indicate their unwillingness to make a certain decision. They used this feature to seek confirmation from others to avoid being blamed for the decision they made. In this research, the researchers found that Mulan also used this feature to 
show her hesitation. She raised her intonation in some conversations to ask for others' confirmation while stating her ideas. It proved that she still lacked the confidence to make a decision. She still faces a fear to state her ideas as a woman as seen in these examples.

\section{Example 3:}

Mulan : Xiu, look at my face. What am I feeling?

Xiu : I have no idea

Mulan : Exactly. This is my sad face? This is my curious face? And now I'm confused.

The conversation of example 3 happened when Mulan was on the way to Matchmaker's place. She did not exactly know what she felt since she just followed the rules, not going there by her desire. For this reason, she felt not sure to state her idea. She used raising intonation on her declarative to ask her sister, Xiu, to give confirmation and decide what kind of expressions that appeared on her face.

\section{Example 4:}

Hong Hui : You can't leave.

Mulan : The emperor gives his permission. But you do not?

In example 4, Mulan delivered her assumption that Hong Hui won't let her go back to her hometown. However, she felt unsure whether her assumption was true or not. She sought confirmation by rising the intonation of her declarative up. It showed that she was not confident to state her understanding of Hong Hui's utterance.

\section{3. 'Empty' Adjectives}

Empty adjectives are adjectives that are more focused on showing emotional reactions rather than bringing specific information (Rahadiyanti, 2020). Women usually used this feature to strengthen the emotional feelings of their utterances. This feature does not mark its user as feminine or effeminate. However, most men tend to avoid using this feature since they think that this feature is more frequent in women's speech and well known as women's words too. However, the researchers found that Mulan consistently used this feature both when she played roles as a woman and as a man as seen in these examples.

\section{Example 5:}

Mulan : Your majesty, I'm deeply honoured by this immeasurable invitation ...

\section{Example 6:}

Mulan (as Hua Jun) : Commander Tung, there's something that weighs heavily on my heart.... 
Examples 5 and 6 proved that Mulan used the 'empty' adjectives feature in some of her utterances both as a woman and as a man. She used this feature to show her emotional reactions. She did not try to avoid this feature even when she played a role as a man since it was her own way to express her feelings. Example 5 showed that Mulan used the word "immeasurable" to express her disbelief and admiration of the award that the emperor would give to her. Meanwhile, example 6 showed that she used the words "weighs heavily" in her utterance to express the great scale of "something" that she felt overburden herself at that time.

\section{Intensifiers}

Genc and Armagan (2018) found that intensifiers are adverbs that can be used to intensify the meaning of other words. In Mulan (2020) movie, the researchers found that Mulan used some adjectives that are categorized as this feature to strengthen her statements and showed her great feelings on something in some particular situations.

\section{Example 7:}

Mulan : You can still take the noble path. It's not too late, please.

\section{Example 8:}

Mulan (as Hua Jun): Just talk to her like you're talking to me now.

Example 7 showed that Mulan used the intensifier "still" and "too" in her utterances to show her great feelings on things she wanted to declare. First, she used the intensifier "still" to emphasize her opinion about "a chance" that she thinks her addressee should take. Then, she added the intensifier "too" in her next sentence to express and emphasize "the quantity of time" of the topic they discussed. Then, in example 8, She used the intensifier "just" to suggest Hong Hui. She expressed her idea by using intensifier even though she appeared as a man. It proved that Mulan used her own way to express her feelings and the features she chose were influenced by her identity as a woman that needs to strengthen the meaning of her utterances to show her strong emotions for that idea.

\section{5. 'Hypercorrect' grammar}

According to Lakoff (1975), women were taught to speak correctly since they were young because they are seen as polite beings in society. They are not supposed to talk rough or being careless with the language they use. This perception makes women pay attention to the way they speak. In forming their utterances, women are rarely using slang (informal language), avoiding offensive language, apologizing more often, and trying to use the most polite forms (Fatmasari \& Gistina, 2020).

In this research, the researchers found that Mulan also used the 'hypercorrect' grammar feature to form her utterances. This finding proved that Mulan's parents educated her to grow up as a good woman for maintaining her status in society. Therefore, she also considered that speaking correctly is important. 


\section{Example 9:}

Mulan : There's a spider crawling in your hair.

\section{Example 10:}

Mulan (as Hua Jun) : : I'm not your friend.

Examples 9 and 10 exposed Mulan's utterances that showed the use of 'hypercorrect' grammar both when she played roles as a woman and as a man. In example 9, Mulan as a woman pronounced the word crawling clearly without modified it or dropped the g's form to change it into crawlin' as most men may do. It proved that she considered herself as a woman who has to speak correctly in society. Then, in example 10, when Mulan acts as Hua Jun (a man), she still used the standard forms. It can be seen from her way of pronouncing the words I'm not. She pronounced it correctly without considering to modified it into ain't which in fact is okay for her surroundings because she appeared as a man. The use of this feature both when she played roles as a woman and as a man was caused by her habits since she was young. She was taught to not speak roughly or to modify particular words to be a good woman for her society. In the movie, if Mulan can appear like a good woman, she can bring honour to her family by being matched for a marriage which was the best thing that a daughter can do at that time.

\section{6. 'Superpolite' forms}

Society has its perception of gender roles and rules for men and women, including the way they speak. Women found that the way they speak would signal their social status in society. They know that society sees them as polite beings, both in the way they speak and behave. For this reason, they have their own ways to make their speech sound more polite and match society's view. They tend to use euphemism and make use of the words "sorry" and "thank you" in their utterances in order to show their politeness.

This feature was also found in Mulan's utterances since she was taught to be a good woman by her parents too. She knew when she should add polite words and when she needed to use euphemism in her utterances as seen in these examples:

\section{Example 11:}

Madam Matchmaker : Is something wrong?

Mulan

: No, madam matchmaker. Thank you.

\section{Example 12:}

Madam Matchmaker: It's ideal for the teapot to remain in the center of the table.

Mulan: Yes, I understand. But I think the teapot should remain where it is.

Examples 11 and 12 showed the 'superpolite' forms feature that Mulan used in her utterances. Mulan used some techniques to make her utterances sound more polite 
to her addressees. In example 11, Mulan added the words "thank you" after refusing Madam Matchmaker's statement. These words were used to show her politeness to the Madam matchmaker. Then, in example 12, Mulan chose to use euphemism to form her speech. She expressed her idea by using the term "the teapot should remain where it is". In this case, the use of euphemism can be seen as Mulan's way to make her speech sounds more polite and to avoid conflict with the Madam Matchmaker. She knew that she suggested something unpleasant for her Madam Matchmaker and it is impolite for her to state it directly. Therefore, instead of saying "the teapot should be there", she used another way to express her suggestion, like "the teapot should remain where it is".

\section{Emphatic Stress}

Emphatic stress is the feature that women use to show the insecurity of their words not being heard seriously by the addressees (Lakoff, 1975). Women use this feature to emphasize and strengthen the meaning of the words they say (Oktapiani, Natsir \& Setyowati, 2017). The researchers found that this feature was the most frequent in Mulan's utterances. It showed that Mulan considered herself as someone who was not playing a powerful role in society. She thought that she should give more effort in her speech to get other's attention and to get approval for something she said.

\section{Example 13:}

Mulan : I'm starving.

In example 13, Mulan used emphatic stress in the word "starving". At that time, she knew that her mother was the one who had the power to take any decision for things she can do. Moreover, she also had an assumption that her mother would not listen to her idea. Therefore, she emphasized the word "starving" to increase her chance to make her mother at least give respond to her idea, even though she also uncertain whether her mother will accept her idea or not.

\section{Example 14:}

Mulan (as Hua Jun) : : I'm Hua Jun. soldier in the emperor's imperial army.

Example 14 showed that Mulan still used emphatic stress to state her idea, even though she played a role as a man. In this example, she used emphatic stress to state her identity that she was also not sure whether it was true or not. She emphasized the words "soldier" and "emperor" because she knew that she was a woman who could not be a soldier in the emperor's imperial army since that position was only for a man. Furthermore, she knew that she introduced herself to a witch that might already know that she was a woman who masqueraded as a man. She used emphatic stress in this utterance to strengthen the power of her speech and to make sure that the witch took her words seriously. 


\section{B. Women's Language Feature that is Not Exist in Mulan (2020) Movie 1. Tag Questions}

Lakoff (1975) stated that most women who use tag questions have already expected that their addresses would agree with their statements because they think that they have enough knowledge on the ideas they convey. The use of this feature is considered as a women's way to make sure that their statements are true and to avoid conflict with others. When analyzing the data, the researchers could not find this feature in Mulan's utterances. The researchers evaluated this phenomenon as the consequence of Mulan's characteristic that was tried to develop in the movie. Mulan was depicted as a strong woman who always followed her conscience. She would take risks to join the imperial army without asking permission from her parents since she believed that she will do it well. Therefore, the non-existence of this feature was considered as the influence of this characteristic. Mulan did not seek confirmation for the things she believed already true.

\section{Precise Color Terms}

The precise color terms feature is used to name or mention a color specifically (Rahmawati, Citraresmana \& Indrayani, 2019). This feature was not found in Mulan (2020) movie since no topic about color was discussed in this movie.

\section{Avoidance of Using Swear Words}

Lakoff (1975) stated that people have many choices to form features and words for their utterances based on the expressions they thought. The researchers found that this statement was related to the non-existence of the avoidance of using swear words feature in Mulan (2020) movie. The non-existence of this feature was considered as Mulan's choice to express her thoughts. Mulan did not choose to use swear words to express her feelings. She chose to state her feelings directly and gave some intonation effects on her utterances. For example, when there was a situation where Mulan was surprised and shocked by the fact that Bory Khan was successfully tricking the army, Mulan did not say any kind of swear words to express her feeling. She expressed it directly by showing her disbelief through her utterance "That can't happen" which stated with a low intonation.

\section{The Frequency Comparison of Women's Language Features Used by Mulan as Mulan and Mulan as Hua Jun}

Table 1. Comparison of Woman's Language Features Found in Mulan's and Hua Jun's Utterances

\begin{tabular}{lccc}
\hline \multicolumn{1}{c}{ Role } & Hua Mulan & Hua Jun & Total \\
\hline LH/F & 8 & 6 & 14 \\
TQ & 0 & 0 & 0 \\
RI & 3 & 0 & 3 \\
\hline
\end{tabular}


Yolanda and Bram, Tell: Teaching of English Language and Literature

Vol. 9, No. 1, April 2021 Doi: http://dx.doi.org/10.30651/tell.v9i1.7207

\begin{tabular}{lccc}
\hline EA & 2 & 1 & 3 \\
PCT & 0 & 0 & 0 \\
IN & 4 & 2 & 6 \\
HG & 4 & 4 & 8 \\
SF & 5 & 2 & 7 \\
SW & 0 & 0 & 0 \\
ES & 14 & 5 & 19 \\
\hline Total & 40 & 20 & 60 \\
\hline
\end{tabular}

After comparing the data of Mulan's utterances as a woman and as a man, the researchers found that there was a reduction of the use of women's language features in her speech when she changed the roles she played from a woman into a man. From the 82 Mulan's utterances, the researchers found that 48 her utterances as a woman named Hua Mulan consisted of 40 women's language features, and the other 34 her utterances as a man named Hua Jun only consisted of 20 women's language features.

These findings showed that when Mulan played a role as a woman, her utterances were more consistent in showing the women's language features which were found 83.33\% from her utterances. However, when she played a role as a man, there were only $58.82 \%$ of her utterances that showed the use of the women's language features.

These results proved that the gender roles in society can influence someone's language use. As the percentage of the use of women's language features when Mulan played a role as a man was smaller than when she played a role as a woman, it can be assumed that she had more confidence in delivering her ideas while she played a role as a man. It was because she did not have to think about her status as a polite being in the society and she should try to adapt with the men in the emperor's imperial army that means that she should not show her feminine way of speaking that clear. Moreover, the fact that she did not seek confirmation anymore when delivering her statement as the rising intonation on declarative features disappeared when she played a role as a man showed that she already considered that her statements as a man were powerful enough to be heard by her surroundings.

However, the researchers evaluated that Mulan still considered her identity as a woman while speaking even though when she played a role as a man. It was because the researchers still found some women's language features on her utterances that indicated her uncertainty and politeness, like lexical hedges/fillers, 'empty' adjectives Intensifiers, 'hypercorrect' grammar, 'Superpolite' forms, and Emphatic stress.

The results that showed the percentage of the women's language features from Mulan's utterances when she played a role as a woman that was $83.33 \%$ and then decreased to $58.82 \%$ when she played a role as a man showed that the gender roles in society take part in forming someone's speech. As the use of the women's language features is to strengthen or emphasize women's speech related to their less confidence of their powerless status in society, the decreasing point of the use of the women's language features by Mulan in this research proved that playing a role as a man helped 
Mulan to feel more confident to state her ideas in society. However, the fact that Mulan still used some of the women's language features when she played a role as a man showed that she still considers her identity as a woman in society. She cannot fully change the way she speaks like a man since she was taught and grew up as a woman who gets used to speak politely since she was young.

\section{Conclusion}

In Mulan (2020) movie, the character Mulan proved that language and society influence each other. The frequency of the women's language features used by Mulan as a man that is lower than as a woman proves that the social perception of gender roles give impact on someone's language use. Then, the fact that Mulan still uses the women's language features in her speech when she plays a role as a man shows that someone's language use is related to someone's role, status, and identity in society. In other words, society plays a role in influencing someone's language use and language plays a role in showing someone's position or status in society.

There were seven out of ten women's language features found in Mulan's utterances, such as lexical hedges/fillers, rising intonation on declaratives, 'empty' adjectives, intensifiers, 'hypercorrect' grammar, super polite' forms, and emphatic stress. The most frequent feature found was emphatic stress, reaching 32\% of Mulan's utterances. As this feature is used to express the speaker's uncertainty, it means that Mulan oftentimes was afraid that her speech was not taken seriously by her addressees. She used an emphatic stress to strengthen her utterances' power to enhance the opportunity of getting her addresses' attention. The researchers evaluated that the factor of this case was the view of the society at that time where women were subordinate to men.

The other three women's language features that were not found in Mulan's utterances were tag questions, precise color terms, and avoidance of using swear words. The researchers found that the non-existence of these features was related to Mulan's character that was developed in its movie, the topics, and also the fact that the use of a language, including the words and features that are used is the speakers' choices based on their thoughts.

\section{References}

Andriani, K. \& Soethama, P.S. (2018). Women's language features in Summer McKeen's vlogs. Jurnal Humanis, 22(3), 735-741.

Apridaningrum, M.C.G., \& Angelina, P. (2020). The existence of women's language features in men and women interaction in the Elle's show. English Language teaching and Research Journal, 3(2), 108-127.

Bengtsson, M. (2016). How to plan and perform a qualitative study using content analysis. NursingPlus Open, 7(2), 4-14.

Eckert, P. \& McGonnel-Ginet, S. (2003). Language and gender. Cambridge: Cambridge University Press.

Fatmasari, Y. \& Gustina, R. (2020). Women language 'hidden figure' movie script written by Allison Shroeder and Theodore Melfi. Metaphor, 2(1), 45-58. 
Genc, Z. S. \& Armagan, K.S. (2018). A cross-cultural investigation of gender-bound language use in Turkish and English plays: Implications for foreign language education. Journal of Education and Training Studies, 6(2), 86-96.

Hancock, B., Windridge K., \& Ockleford E. (2009). An introduction to qualitative research. The NIHR RDS EM/YH.

Holmes, J. (2013). An introduction to sociolinguistics (4 ${ }^{\text {th }}$ ed.). New York: Routledge.

Janah, N. D. \& Tarwiyah, S. (2017). Male and female speech in pride and prejudice novel by Jane Austen and its implication in teaching speaking. Vision: Journal for Language and Foreign Language Learning, 6(2), 109-121.

Kurniaty, N. (2018). Women's language in the movie script of the perks of being a wallflower. Jurnal Humanis, 22(2), 542-548.

Lakoff, R. (1975). Language and woman's place. New York: Harper \& Row.

Lubis, F., K. \& Bahri, S. (2020). Women language in Indonesian television talk show. Journal of UCYP Press, 2(2), 37-46.

Oktapiani, T., Natsir, M., \& Setyowati, R. (2017). Women's language features found in female character's utterances in the devil wears Prada movie. Jurnal Ilmu Budaya, 1(3) 207-220.

Oxford University Press. (2015). Gender. In Oxford advanced learner's dictionary ( $9^{\text {th }}$ ed., p, 632).

Rahadiyanti, I. (2020). Women language features in Tennessee Williams' a streetcar named Desire. Vivid: Journal of Language and Literature, 9(2) 86-92.

Rahmawati, D., Citralesmana, E. \& Indrayani, L.M. (2019). Women language features in recode world's technology conference: A sociolinguistic studies. ELT, 22(3), 735-741.

Susanti, V.M.D \& Aryani, I.G.A.I. (2018). Women's language in "bring it on" movie. Jurnal Humanis, 22(3), 836-841.

Wahyuningsih, S. (2018). Men and women differences in using language: A case study of students at STAIN Kudus. Edulite Journal of English Education, Literature, and Culture, 3(1), 79-90.

Wardani, F. R., \& Kristiani, M. K. (2017). Women's language features in Michelle Obama's speech "the first lady on the importance of studying abroad". ELTR Journal, 1(2), 23-34.

Yunnisa, I. S., Arman \& Amstrong, N. (2020). Women's language in the devil wears Prada movie script by David Frankel. ELITE: Journal of English Language and Literature, 3(1), 51-60. 